\title{
Mitigating Ammonia Volatilization from Waterlogged Acids Soils Using Organic Amendments
}

\author{
Maru Ali ${ }^{1}$, Ahmed Osumanu Haruna ${ }^{1,2,3}$, Nik Muhamad Abd Majid ${ }^{3}$, Walter Charles Primus ${ }^{4}$, Audrey Asap ${ }^{1}$, \\ Nathaniel Maikol ${ }^{1} \&$ Alicia Vanessa Jeffary ${ }^{1}$ \\ ${ }^{1}$ Department of Crop Science, Faculty of Agriculture and Food Sciences, Universiti Putra Malaysia Bintulu \\ Campus, 97008 Bintulu, Sarawak, Malaysia \\ ${ }^{2}$ Agriculture and Environment, Borneo Eco-Science Research Center, Faculty of Agriculture and Food Sciences, \\ Universiti Putra Malaysia Bintulu Sarawak Campus, 97008 Bintulu, Sarawak, Malaysia \\ ${ }^{3}$ Institute of Tropical Forestry and Forest Products (INTROP), Universiti Putra Malaysia, 43400 Serdang, \\ Selangor, Malaysia \\ ${ }^{4}$ Department of Basic Science and Engineering, Faculty of Agriculture and Food Sciences, Universiti Putra \\ Malaysia Bintulu Campus, 97008 Bintulu, Sarawak, Malaysia
}

Correspondence: Ahmed Osumanu Haruna, Department of Crop Science, Faculty of Agriculture and Food Sciences, Universiti Putra Malaysia Bintulu Campus, 97008 Bintulu, Sarawak, Malaysia. E-mail: osumanuharuna@gmail.com

Received: December 14, 2018 Accepted: January 4, 2019 Online Published: May 14, 2019

doi:10.5539/sar.v8n3p12

URL: https://doi.org/10.5539/sar.v8n3p12

\begin{abstract}
In production agriculture, granular urea is the most used nitrogen fertilizer in crop production. However, increase in soil $\mathrm{pH}$ following application of urea causes ammonia volatilization and reduces $\mathrm{N}$ use efficiency. To minimize ammonia loss, organic amendments are used, however, type of organic amendment use could affect urea use efficiency. This study was to determine the effects of organic amendments derived from forest litter, Leucaena leucocephala, chicken litter, and cow dung on ammonia volatilization and chemical properties of a waterlogged acid soil. Treatments evaluated were: (i) T1, Soil only, (ii) T2, Existing recommended fertilization, (iii) T3, Biochar-forest litter compost, (iv) T4, Biochar-chicken litter compost, (v) T5, Biochar-cow dung compost, (vi) T6, Biochar-Leucaena compost, and (vii) T7, Biochar-Leucaena - chicken litter compost. Standard procedures were used to quantify ammonia volatilization and soil chemical properties. The findings of this present study also revealed that the total amount of ammonia loss from urea over a period of forty-two days depends on the influence of the organic amendments on urea hydrolysis. Emissions of ammonia from T6 and T7 were significantly higher because, the decomposition of Leucaena leucocephala favours urea hydrolysis compared with those of T3, T4, and T5. Therefore, Leucaena leucocephala composts should be carefully co-applied with urea to minimize ammonia loss if the aim of using this type of amendments is to improve $\mathrm{N}$ use efficiency and soil and crop productivity.
\end{abstract}

Keywords: agricultural wastes, ammonia volatilization, chemical fertilizers, soil organic amendments, urea hydrolysis

\section{Introduction}

Rice (Oryza sativa L.) is one of the most consumed grain crops in the world (IRRI, 2006). Among the three major nutrients used in rice production, nitrogen is generally used in large quantity for many rice cultivars (Kong et al., 2008). Although calcium ammonium nitrate and ammonium sulphate are used in crop production, granular urea is the most used nitrogen fertilizer in the world (Basosi et al., 2014). Even though urea is prone to ammonia volatilization, out of the 190 million tons of the yearly production of urea, approximately $80 \%$ is used in crop production especially in rice cultivation (Basosi et al., 2014). Ammonia volatilization occurs in acid soils because of high pH at the spot where urea touches soils (Prasertsak et al., 2001). High pH at the soil microsite is because of increase in $\mathrm{OH}^{-}$. This process shifts urea hydrolysis more to ammonia emission (Fan \& Mackenzie, 1993).

Composts and biochars which are rich in humic substances have been used to minimize ammonia volatilization 
because of their high affinity for the carboxylic and phenolic functional groups of the humic substances for ammonium ions (Tan, 2003). In order words, the affinity of the carboxylic and phenolic functional groups of the humic substances in composts and biochars protects ammonium ions from being converted to ammonia (Siva et al., 1999; Castells et al., 2004). For example, Palanivell et al. (2017) used chicken litter biochar to minimize ammonia loss from a waterlogged acid soil. It had also been reported that composts and biochars can stimulate heterotrophs to immobilize N (Castells et al., 2004; Choi \& Chang, 2005). Such abiotic N fixation can also contribute to retention of $\mathrm{NH}_{4}{ }^{+}$to minimize ammonia volatilization (Siva et al., 1999). This reaction may be viewed as a positive interaction between soil organic amendments and Urea-N (Choi et al., 2001).

However, improper use of soil organic amendments could have some adverse effects on soil nutrient management. For example, the high $\mathrm{pH}$ of a number of soil organic amendments tends to increase soil $\mathrm{pH}$ such that urea is rapidly hydrolyzed to produce ammonia. Organic amendments can also stimulate ureolytic microorganisms in soils to trigger ammonia loss through urea hydrolysis (Fan \& Mackenzie, 1993). Hence, there is the need to determine the effects of different organic amendments especially those that are produced from forest litter, Leucaena leucocephala, chicken litter, and cow dung on ammonia volatilization. In this study, it was found that the negative effects of organic amendments depend on their raw materials used. To this end, the objective of this study was to determine the effects of organic amendments which are produced from forest litter, Leucaena leucocephala, chicken litter, and cow dung on ammonia volatilization and chemical properties of waterlogged tropical acid soils.

\section{Materials and Methods}

An incubation study was carried out using Typic Paleudults (Nyalau Series) (Paramanathan, 2000). This soil was taken from a secondary forest with geographical coordinates of latitude $3^{\circ} 12^{\prime} 15.45^{\prime \prime} \mathrm{N}$ and longitude $113^{\circ} 04^{\prime}$ $15.82^{\prime \prime}$ E, Bintulu, Sarawak, Malaysia. The soil was taken at a depth of $0-25 \mathrm{~cm}$ after which it was transported to the Research Complex of Universiti Putra Malaysia Bintulu Sarawak Campus, Malaysia. Thereafter, the soil samples were air dried at room temperature and crushed to pass a $5 \mathrm{~mm}$ sieve to remove twigs, plant roots, and ironstone concretions. Before the incubation study, the soil chemical properties were determined (Table 1). The results in Table 1 are similar to those of Palanivell et al. (2017; 2016).

Table 1. Selected chemical properties of Typic Paleudults (Nyalau Series) before ammonia volatilization study

\begin{tabular}{|c|c|c|c|}
\hline Properties & Values & Properties & Values \\
\hline \multirow[t]{2}{*}{$\mathrm{pH}$ in water } & $4.9 \pm 0.04$ & & $\ldots \ldots \mathrm{cmol} \mathrm{kg}^{-1}$ \\
\hline & ........\% & Available K & $1.01 \pm 0.12$ \\
\hline Total carbon & $1.25 \pm 0.10$ & Total K & $3.30 \mathrm{a} \pm 1.14$ \\
\hline \multirow[t]{2}{*}{ Total N } & $0.05 \pm 0.007$ & CEC & $4.58 \pm 0.10$ \\
\hline & $\ldots \ldots \ldots \mathrm{mg} \mathrm{kg}^{-1} \ldots \ldots \ldots$ & Exchangeable Acidity & $1.32 \pm 0.07$ \\
\hline Available $\mathrm{NO}_{3}^{-}$ & $1.05 \pm 0.35$ & Exchangeable $\mathrm{Al}^{3+}$ & $1.24 \pm 0.05$ \\
\hline Exchangeable $\mathrm{NH}_{4}^{+}$ & $1.58 \pm 0.18$ & Exchangeable $\mathrm{H}^{+}$ & $0.08 \pm 0.02$ \\
\hline Available P & $2.84 \pm 0.64$ & Exchangeable $\mathrm{Cu}^{2+}$ & $0.0119 \pm 0.0006$ \\
\hline \multirow[t]{6}{*}{ Total P } & $64.80 \pm 4.64$ & Exchangeable $\mathrm{Mn}^{2+}$ & $0.27 \pm 0.07$ \\
\hline & & Exchangeable $\mathrm{Fe}^{2+}$ & $0.16 \pm 0.01$ \\
\hline & & Exchangeable $\mathrm{Zn}^{2+}$ & $0.0068 \pm 0.0008$ \\
\hline & & Exchangeable $\mathrm{Na}^{+}$ & $5.25 \pm 0.39$ \\
\hline & & Exchangeable $\mathrm{Ca}^{2+}$ & $26.39 \pm 2.76$ \\
\hline & & Exchangeable $\mathrm{Mg}^{2+}$ & $5.27 \pm 0.93$ \\
\hline
\end{tabular}

Soil $\mathrm{pH}$ was determined in a 1:2.5 (soil: distilled water) using a digital $\mathrm{pH}$ meter (Peech et al., 1965). Soil total C was calculated as $58 \%$ of the organic matter which was determined using the loss of weight on ignition method (Cheftez et al., 1996). Cation exchange capacity (CEC) of the soil was determined using the leaching method (Cottenie, 1980) followed by steam distillation (Bremner, 1965). Exchangeable cations were extracted with $1 \mathrm{M}$ $\mathrm{NH}_{4} \mathrm{OAc}$ using the leaching method (Cottenie, 1980) after which the extracted cations were determined using Atomic Absorption Spectrometer (AAnalyst 800, PERKIN Elmer Instruments, Norwalk, CT). Total N was 
determined using Kjeldhal method (Tan, 2005) whereas $\mathrm{NO}_{3}{ }^{-}$and $\mathrm{NH}_{4}{ }^{+}$were determined using Keeney and Nelson (1982) method. Soil total P and K were extracted using the Aqua Regia method. Thereafter, total P was determined using Spectrophotometer after blue colour development using the Blue Method (Murphy \& Riley, 1962) whereas total K was determined using Atomic Absorption Spectrometry (AAnalyst 800, Perkin Elmer Instrument, Norwalk, CT). Soil exchangeable acidity, $\mathrm{H}^{+}$, and $\mathrm{Al}^{3+}$ were determined using the acid-base titration method (Rowell, 1994). These soil chemical properties analyzes were repeated after the incubation study.

\subsection{Chemical Composition of Organic Amendments Used}

The forest litter, Leucaena leucocephala, chicken litter, and cow dung used in this study were sourced in Bintulu, Sarawak, Malaysia. The samples were processed in a Research Complex of Universiti Putra Malaysia Bintulu Sarawak Campus, Malaysia using standard procedures. The selected chemical properties of the organic amendments produced from Chicken litter biochar, forest litter, Leucaena leucocephala, chicken litter, and cow dung were determined using standard procedures (Table 2).

Table 2. Selected chemical properties of organic amendments derived from chicken litter biochar, forest litter, Leucaena leucocephala, chicken litter, and cow dung

\begin{tabular}{lccccccc}
\hline & $\mathbf{p H}$ & Ash content & Total C & Total N & Total P & Total K & Total Mg \\
\cline { 2 - 8 } & \multicolumn{7}{c}{$\ldots \ldots \ldots \ldots \ldots \ldots \ldots \ldots \%$} \\
\cline { 2 - 8 } $\begin{array}{l}\text { Chicken litter biochar-forest } \\
\text { litter compost (1:1) }\end{array}$ & 8.52 & 47 & 31 & 0.64 & 1.85 & 38.53 & 1.24 \\
$\begin{array}{l}\text { Chicken litter biochar-chicken } \\
\text { litter compost (1:1) }\end{array}$ & 7.39 & 33 & 39 & 0.20 & 1.44 & 38.32 & 1.37 \\
$\begin{array}{l}\text { Chicken litter biochar-cow dung } \\
\text { compost (1:1) }\end{array}$ & 9.25 & 45 & 32 & 0.28 & 2.99 & 39.99 & 1.77 \\
$\begin{array}{l}\text { Chicken litter biochar-Leucaena } \\
\text { compost (1:1) }\end{array}$ & 8.44 & 62 & 22 & 0.14 & 1.83 & 38.28 & 1.40 \\
$\begin{array}{l}\text { Chicken litter biochar-Leucaena } \\
\text { - chicken litter compost (2:1:1) }\end{array}$ & 8.62 & 43 & 33 & 0.28 & 2.31 & 39.58 & 1.61 \\
\hline
\end{tabular}

Amounts of the organic amendments used were based on $5 \mathrm{t} \mathrm{ha}^{-1}$ (Maru et al., 2015) (Tables 3 and 4).

Table 3. Treatments evaluated in the volatilization study

\begin{tabular}{ll}
\hline Treatment codes & Treatments \\
\hline T1 & Soil only \\
T2 & 100\% (N, P, K, and Mg) recommended fertilization* \\
T3 & Chicken litter biochar-forest litter compost $(1: 1)$ \\
T4 & Chicken litter biochar-chicken litter compost $(1: 1)$ \\
T5 & Chicken litter biochar-cow dung compost $(1: 1)$ \\
T6 & Chicken litter biochar-Leucaena compost (1:1) \\
T7 & Chicken litter biochar-Leucaena - chicken litter compost $(2: 1: 1)$ \\
\hline
\end{tabular}


Table 4. Amounts of soil, organic amendments, and urea used in the volatilization study

\begin{tabular}{ccccc}
\hline Treatments & Soils & Organic amendments type & Amount of compost & Urea \\
\hline & $\ldots . \mathrm{g} \ldots .$. & - & $\ldots \ldots . \mathrm{g} \ldots \ldots$. \\
T1 & 1000 & - & - & - \\
T2 & 1000 & & - & 1.32 \\
T3 & 1000 & Chicken litter biochar-forest litter compost & 20 & 1.32 \\
T3” & 1000 & & 22 & - \\
T4 & 1000 & Chicken litter biochar-chicken litter compost & 20 & 1.32 \\
T4” & 1000 & & 20 & - \\
T5 & 1000 & Chicken litter biochar-cow dung compost & 20 & 1.32 \\
T5” & 1000 & & 20 & - \\
T6 & 1000 & Chicken litter biochar-Leucaena compost & 20 & 1.32 \\
T6" & 1000 & & 20 & - \\
T7 & 1000 & Chicken litter biochar-Leucaena - chicken litter compost & 20 & 1.32 \\
T7” & 1000 & & 20 & - \\
\hline
\end{tabular}

Note: Treatments with “, (T3”, T4”, T5”, T6”, T7”) are treatments without urea

\subsection{Ammonia Volatilization Setup}

Plastic containers were filled with $1 \mathrm{~kg}$ soil based on the soil's bulk density $\left(1.16 \mathrm{~g} \mathrm{~cm}^{-3}\right)$. Rates of the organic amendments and the amount of urea recommended by Maru et al. (2015) and MADA (2015), respectively were scaled down based on the requirement of rice plants (Table 2). Ammonia volatilization was measured using a closed dynamic air flow system (Siva et al., 1999; Ahmed et al., 2006, Palanivell et al., 2017) with modification. The system consisted of air pumps which were connected to containers with treatments using polyethene tubing (Figure 1). The incubation chambers were maintained at room temperature. Air was passed through the closed system at a rate of $3.5 \mathrm{~L}^{-1} \mathrm{~min}^{-1}$ chamber ${ }^{-1}$. This rate of airflow which is equivalent to 8.5 volume exchanges $\min ^{-1}$, was maintained throughout the incubation study using a Gilmont flow meter (Gilmont Instrument, Great Neck, NY, USA). The outlet of each container was connected to a conical flask with $75 \mathrm{~mL}$ boric acid solution using a polyethene tube. In the conventional method, only one conical flask with $75 \mathrm{~mL}$ boric acid solution is used but in this present study, three conical flasks connected in series using polyethene tubes were used (Figure 1). This modification is essential because the ammonia captured in the $75 \mathrm{~mL}$ of boric acid solution in only one conical flask requires accurate trapping of ammonia to avoid underestimation of this gas.

Our preliminary trials revealed that excess ammonia was lost when only one conical flask with $75 \mathrm{~mL}$ boric acid solution was used due to saturation of the boric acid over 24 hours. Moreover, it was hard to know if the boric acid had captured enough ammonia for it to be changed within the 24 hours. However, with the three-capturing conical flasks with the boric acid solution in series, avoidance of the underestimation of ammonia loss was possible (Figure 1) as excess ammonia were captured in the boric acid solutions of the second and third conical flasks. This means that, with this new approach of using 3 sets of conical flasks each with $75 \mathrm{~mL}$ boric acid solution, all of the ammonia released within 24 hours were captured. The captured ammonia was back titrated with $0.01 \mathrm{M} \mathrm{HCl}$ to estimate the daily percentages of the ammonia released from urea. Measurements were continued until the ammonia loss decline to $1 \%$ of the $\mathrm{N}$ added from urea (Ahmed et al., 2006).

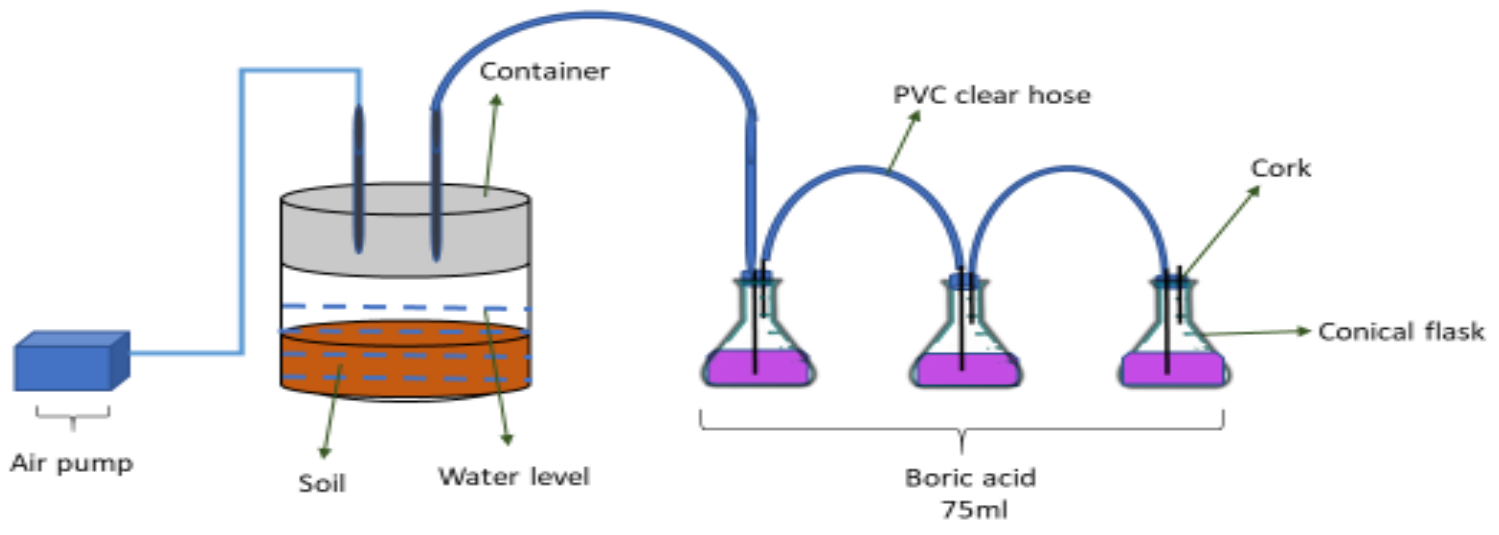

Figure 1. Close-dynamic air flow system with modification (Siva et al., 1999; Ahmed et al., 2006) 
The ammonia loss determination carried out for 42 days and thereafter, the ammonia volatilization study was stopped. At the end of the ammonia volatilization study, soil samples were processed and analysed using the standard procedures outlined earlier.

\subsection{Statistical Analysis}

Analysis of variance (ANOVA) was used to detect significant differences among treatments, whereas Tukey's HSD test was used to compare treatment means using Statistical Analysis System version 9.2 (SAS, 2008).

\section{Results and Discussion}

\subsection{Co-application of Organic Amendments and Urea on Daily Ammonia Loss}

Throughout the 42 days of the ammonia volatilization study, soil only (T1) did not cause ammonia emission (Figure 2) and this confirms the findings of Palanivell et al. (2016) that soils without urea or soil amendments such as composts do not emit ammonia (Fageria, 2016). Ammonia emission from T2 started on day 11 but most of the Urea-N got lost between day 17 and day 42 (Figure 2) (Palanivell et al. 2017). The ammonia emission was delayed for 10 days because the rapid hydrolysis of urea was impeded due to the acidity of tropical soils (Zhou et al., 2014). The hydrogen ions of tropical soils are able to temporary retard the activities of urease, an enzyme that plays a significant role in catalyzing urea hydrolysis (Palanivell et al., 2016). It must be stressed that the time taken for significant amount urea-N loss through ammonia volatilization depends on the amount of urea used as the higher amount of urea leads to more ammonia loss in a relatively shorter period. For T3, T4, and T5, the ammonia loss started on day 2 whereas, in T6, the highest ammonia volatilization occurred between days 4 and 5. On day 5, ammonia emissions from the soils with T5 and T6 were similar (Figure 2). Between days 6 and 11, T4 showed the highest percentage of ammonia loss (Figure 2). Among the organic amendment treatments, T4 showed the highest percentage of ammonia volatilization on day 7 (Figure 2).

The ammonia emitted from the soils with organic amendments is related to the humic substances of the organic amendments used in this study as the amendments were able to fix $\mathrm{Al}^{3+}$ and $\mathrm{Fe}^{3+}$ ions. This reaction reduces $\mathrm{Al}^{3+}$ and $\mathrm{Fe}^{3+}$ concentrations in the soil solution thereby reducing $\mathrm{Al}^{3+}$ and $\mathrm{Fe}^{3+}$ hydrolysis to produce more $\mathrm{H}^{+}$. Instead, more $\mathrm{OH}^{-}$were produced from urea hydrolysis to increase soil $\mathrm{pH}$. Soil $\mathrm{pH}$ enhances urea hydrolysis because it is a process that causes ammonia volatilization due to the decrease in $\mathrm{H}^{+}$ions (Fan \& Mackenzie, 1993). Additionally, there was ammonia volatilization because ureolytic microorganisms in the organic amendments might have catalyzed urea hydrolysis (Figure 2) (Choi, 2007).

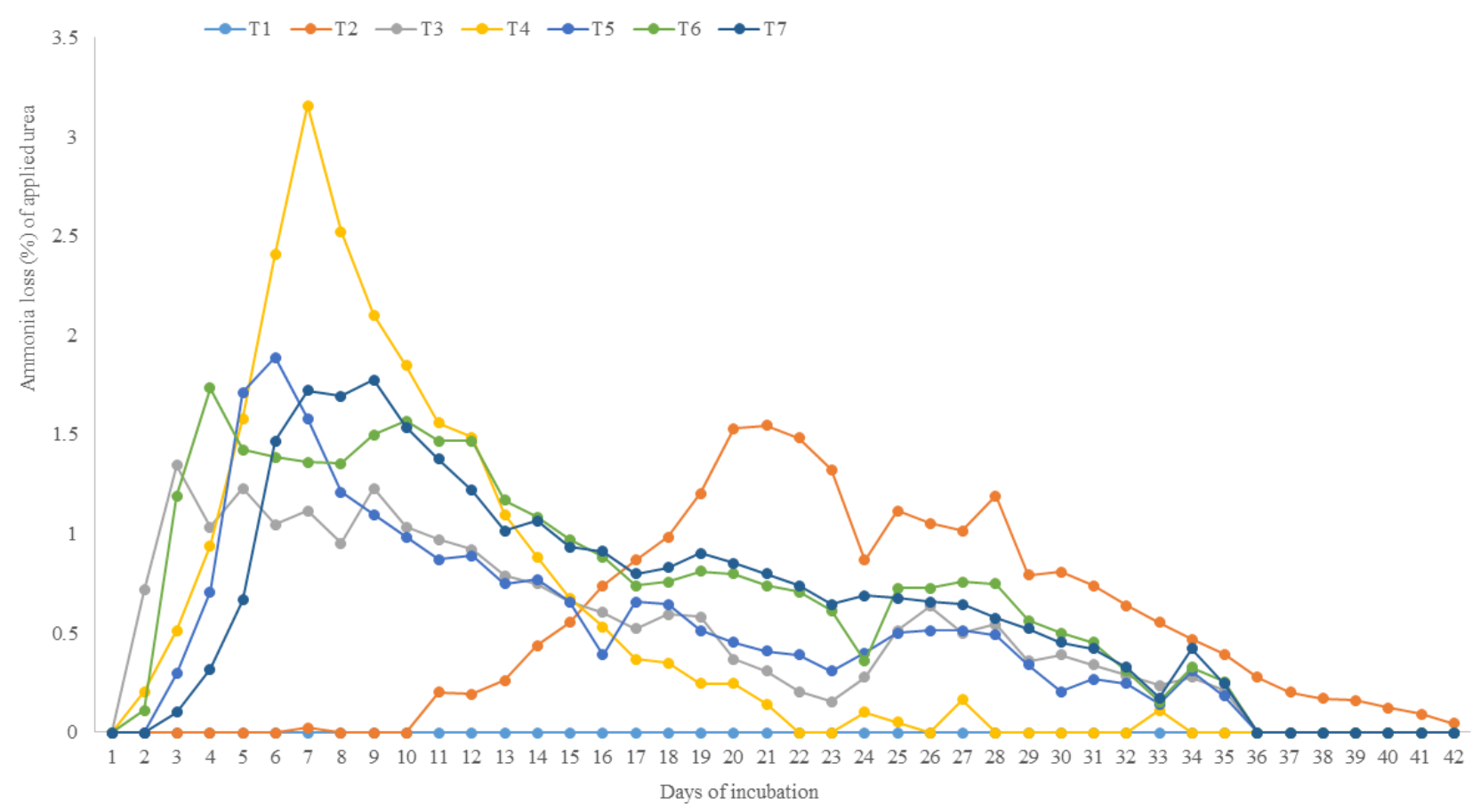

Figure 2. Daily ammonia losses following application of soil organic amendments and urea 


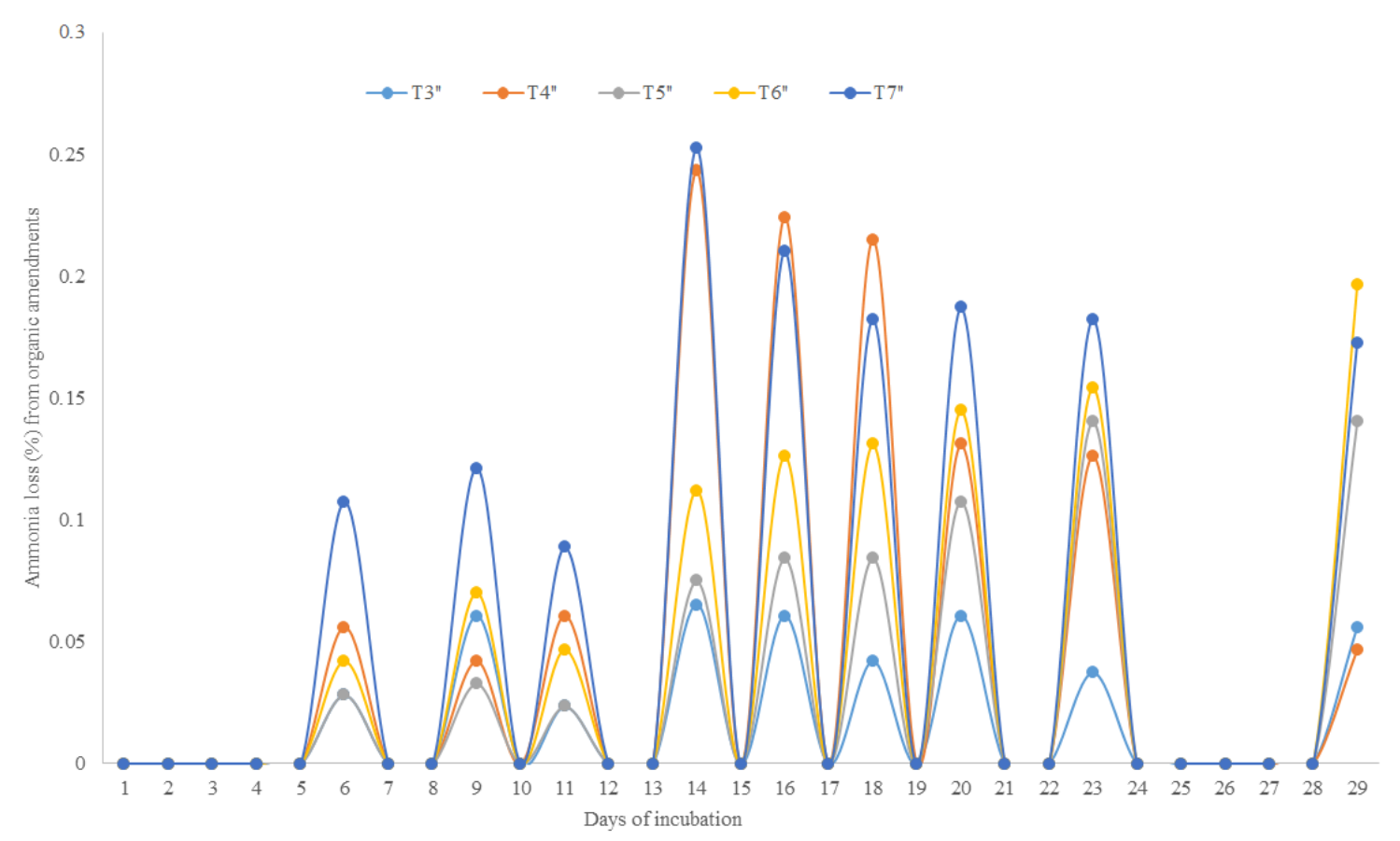

Figure 3. Daily effects of organic amendments on ammonia loss without urea application

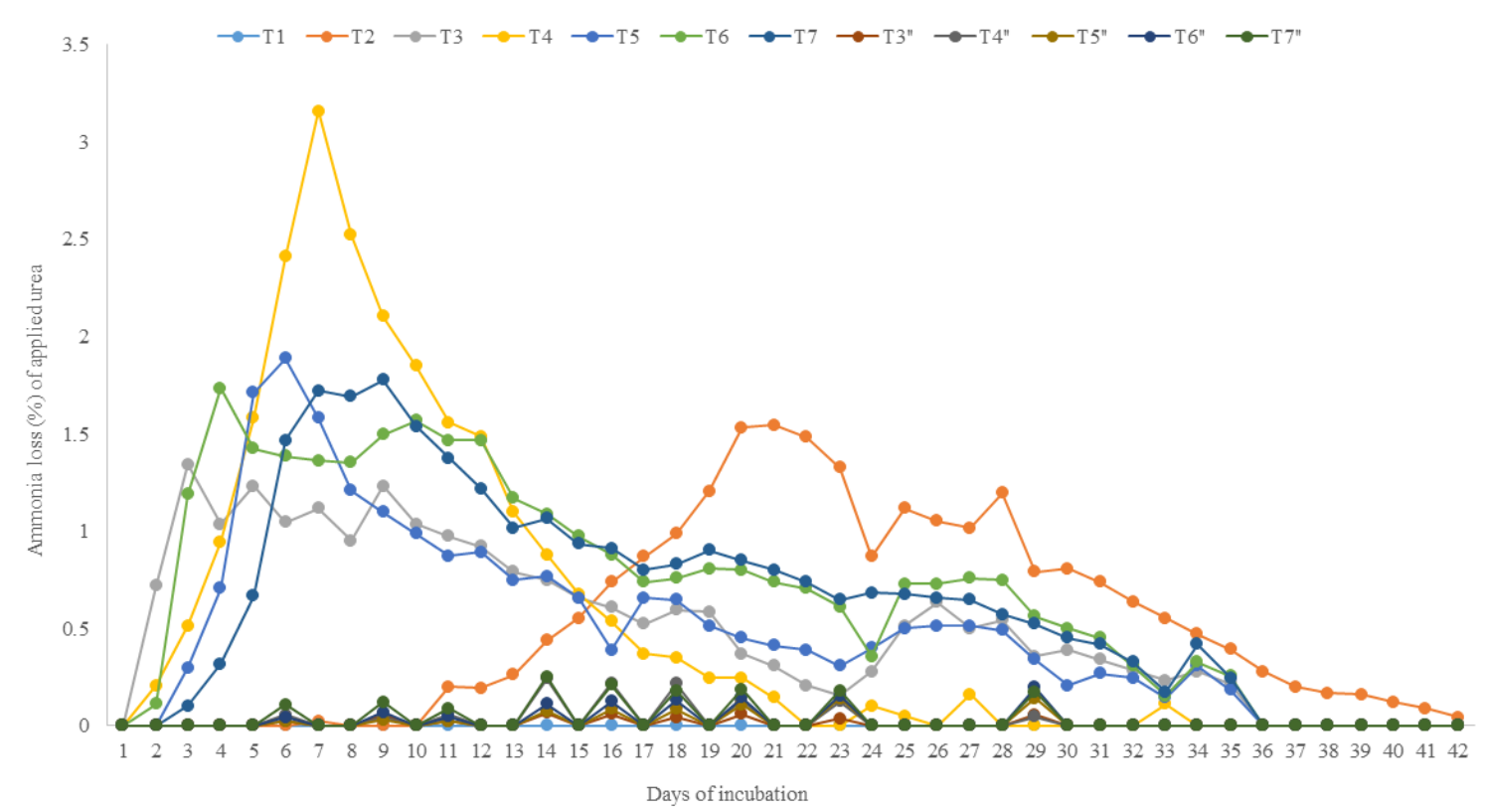

Figure 4. General overview of ammonia losses from organic amended soils with and without chemical fertilizers

Note: Treatments 3", 4", 5" 6", and 7" are repetition of treatments 3, 4, 5 6, and 7 respectively, but indicate without the use of urea application.

\subsection{Effects of Organic Amendments Only on Daily Ammonia Loss}

Ammonia volatilization from soils with organic amendments without urea (T3", T4", T5", T6", and T7") started on day 6 (Figure 3) but the losses were less than $0.26 \%$ (Figure 3). These results suggest that the organic amendments only did not cause significant ammonia emission. Treatment 3", T4", T5", T6", and T7" delayed ammonia volatilization for 4 days compared with T3, T4, T5, T6, and T7 (treatments with urea) (Figure 4) because of the low nitrogen contents of the organic amendments. These findings further suggest that the ammonia volatilization through co-application of the organic amendments and urea was due to the effects of the 
organic amendments on urea and not ammonia from the organic amendments.

\subsection{Effects of Soil Organic Amendments with and Without Urea on Total Ammonia Loss}

The total ammonia loss over 42 days are summarized in Figures 5 and 6 . The fact that the total ammonia released from T4 within 42 days was similar to those of T2, T3, and T5 but significantly lower than those of T6 and T7 (Figure 5) suggests that urea should be applied after 7 days of organic amendment application. Treatment 3 showed a well-distributed release of ammonia, suggesting the suitability of this treatment to control ammonia volatilization. Furthermore, T3 will ensure uniform soil $\mathrm{N}$ availability compared with T4, T5, T6, and T7. Among the treatments with organic amendments, T6 and T7 caused significant emissions of ammonia compared with T3, T4, and T5 because of the lower C:N ratio. Moreover, the ureolytic microorganisms of the organic amendments in T6 and T7 stimulated urea hydrolysis to cause rapid release of ammonia (Choi, 2007).

The organic amendments of $\mathrm{T} 3, \mathrm{~T} 4$, and $\mathrm{T} 5$ were expected to increase soil $\mathrm{NH}_{4}{ }^{+}$availability than in $\mathrm{T} 2$ but the total ammonia losses of T3, T4, and T5 were not significantly different from that of T2 due to enhanced soil heterotrophs. These organisms are known to immobilize excess $\mathrm{NH}_{4}{ }^{+}$(Siva et al., 1999; Han et al., 2004). It was also possible that the microbial immobilization of excess $\mathrm{NH}_{4}{ }^{+}$reduced the release of $\mathrm{N}$ from T3, $\mathrm{T} 4$, and $\mathrm{T} 5$ (Castells et al., 2004; Choi \& Chang, 2005). Moreover, the affinity of the negatively charged sites of the organic matter associated with T3, T4, and T5 for $\mathrm{NH}_{4}{ }^{+}$contributed to good retention of $\mathrm{NH}_{4}{ }^{+}$in the soil solution thereby minimizing ammonia volatilization (Siva et al., 1999; Castells et al., 2004). The results in Figure 6 suggest that the ammonia volatilization depends on how the organic amendments affected urea hydrolysis rather than ammonia loss from the organic amendments. Amending the soils with the organic amendments only did not significantly increase ammonia volatilization compared to the urea and organic amendments (Figure 4). This observation further suggests that ammonia volatilization following co-application of urea and organic amendments was principally due to the effects of the organic amendments on urea and not from the organic amendments. In general, co-application of urea and organic amendments caused higher ammonia volatilization. The treatments with Leucaena leucocephala (T7 and T6) showed the highest ammonia emission compared with the recommended fertilization (T2), forest litter (T3), chicken litter (T4), and cow dung (T3) amendments.

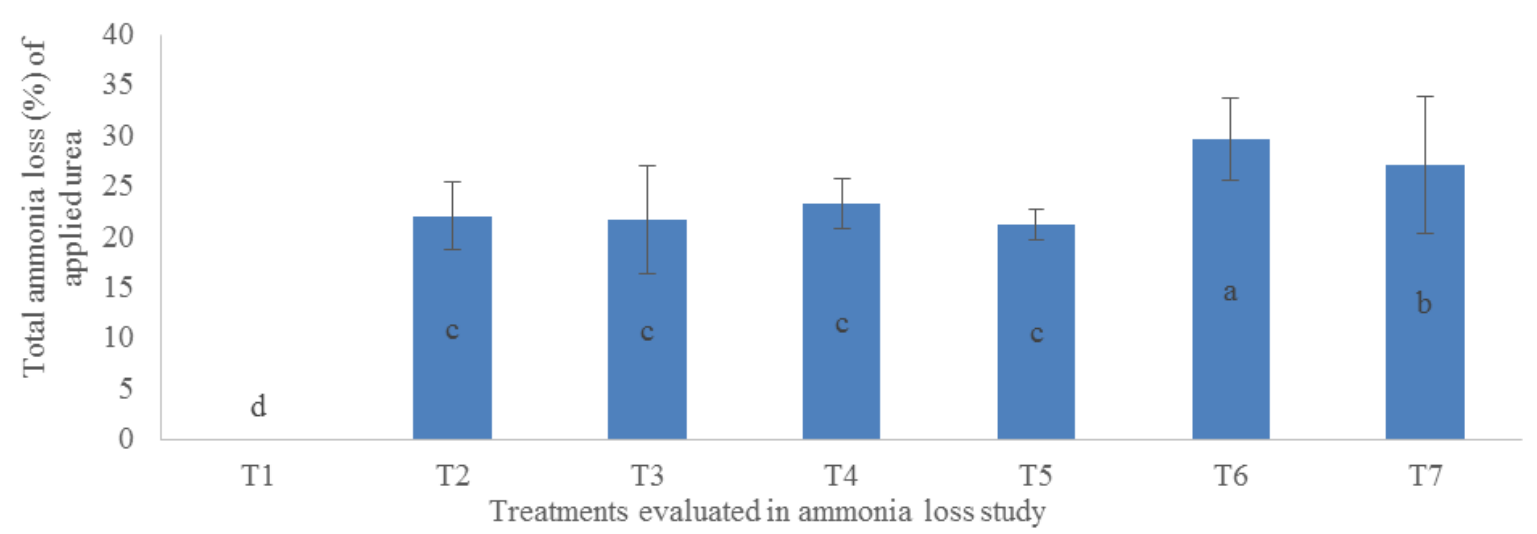

Figure 5: Effects of soil organic amendments on total ammonia loss over forty-two days of incubation 


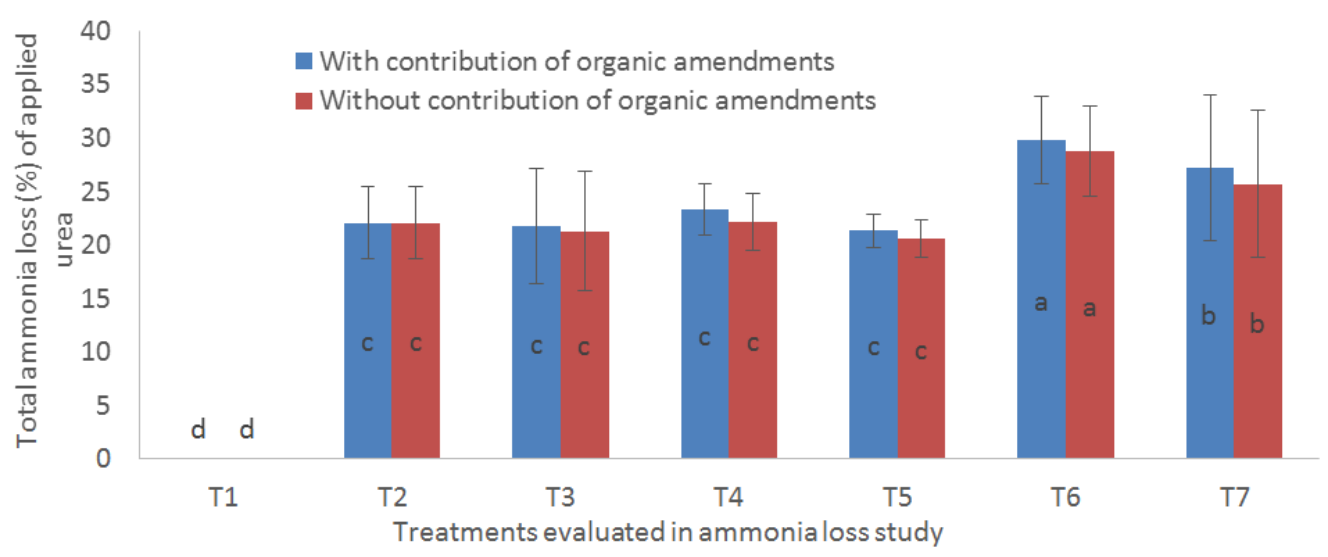

Figure 6. Soil total ammonia losses over for forty-two days with and without the contribution of organic amendments

\subsection{Effects of Organic Amendments on Soil Chemical Properties at Forty-two days of Ammonia Volatilization}

The soil chemical properties at 42 days of ammonia volatilization are shown in Table 4 . Total carbon and $\mathrm{pH}$ in water and $\mathrm{KCl}$ of T3, T4, T5, T6, and T7 were significantly higher than those of T1 and T2. Soil pH of T7 was similar to those of $\mathrm{T} 6$ and $\mathrm{T} 5$ (Table 4) because of the higher carboxylic- $\mathrm{COOH}$ and phenolic-OH groups associated with the chicken litter biochar, forest litter, Leucaena leucocephala, chicken litter, and cow dung amendments. The total acidity and $\mathrm{H}^{+}$of $\mathrm{T} 1$ and $\mathrm{T} 2$ were significantly higher than those of $\mathrm{T} 3, \mathrm{~T} 4, \mathrm{~T} 5, \mathrm{~T} 6$, and T7. Soil exchangeable $\mathrm{Al}^{3+}$ could not be detected in T3, T4, T5, T6, and T7. The significant reduction in $\mathrm{Al}^{3+}$ explains the reduction of the soil acidity (Cheng et al., 2008; Maru et al., 2015). Treatments 3, 4, 5, 6, and 7 increased sorption of $\mathrm{Al}^{3+}, \mathrm{Fe}^{3+}$, and $\mathrm{Cu}^{2+}$ (Table 4) because of the high affinity of these ions for the humic and fulvic acids of the organic amendments (Clemente et al., 2006). Although $\mathrm{T} 2$ had no organic amendment, $\mathrm{Al}^{3+}$ was not detected because $\mathrm{Al}^{3+}$ might have been hydrolyzed to produce more $\mathrm{H}^{+}$.

Total carbon of T3, T4, T5, T6, and T7 were similar but significantly higher than those of T2 and T1 (Table 4) because of the organic matter in the former treatments (Palanivell et al., 2017). The carbon of T1 and T2 were lower because of the inherent organic matter of the soil (Paramananthan, 2000). Total $\mathrm{N}$ of $\mathrm{T} 7$ was similar to those of T3, T4, T5, and T6 but significantly higher than those of T2 and T1 (Table 4) because of the higher $\mathrm{N}$ contents in the Leucaena leucocephala and chicken litter amendments. Also, the $\mathrm{NO}_{3}{ }^{-}$of $\mathrm{T} 2$ and $\mathrm{T} 5$ were similar to those of T4 and T5 but significantly higher than those of T1, T3, and T6. Ammonium of T2 was significantly higher than those of T1, T3, T4, T5, T6, and T7 because of the prolonged emission of ammonia (42 days of ammonia emission) from (T2), suggesting that the soil with $\mathrm{T} 2$ had a significant amount of $\mathrm{NH}_{4}{ }^{+}$which could further be lost through volatilization.

Total P of T4 was similar to those of T2, T3, T5, and T7 but significantly higher than those of T1 and T6 (Table 4). Also, available $\mathrm{P}$ of $\mathrm{T} 4$ was significantly higher than those of T1, T2, T3, T5, T6, and T7. Available P of T2 was similar to those of T5 and T7 but significantly higher than those of T1, T3, and T6. Total K of T4 was similar to that of T7 but significantly higher than those of T1, T2, T3, T5, and T6 (Table 4). However, available $\mathrm{K}$ of T4, T6, and T7 were significantly higher than those of T1, T2, T3, and T5. Available K of T3 and T5 were also significantly higher than those of $\mathrm{T} 1$ and $\mathrm{T} 2$. The higher $\mathrm{P}$ and $\mathrm{K}$ contents of $\mathrm{T} 4$ were due to the inherent or native $\mathrm{P}$ and $\mathrm{K}$ contents of the poultry manure used in producing the organic amendment (T4).

Exchangeable $\mathrm{Na}, \mathrm{Ca}, \mathrm{Mg}$, and $\mathrm{Mn}$ of $\mathrm{T} 1$ and $\mathrm{T} 2$ were lower than in the soils with the organic amendments (T3, T4, T5, T6, and T7) (Table 4). Exchangeable Zn of T4 was similar to those of T5, T6, and T7 but significantly higher than those of T1, T2, and T3. Exchangeable $\mathrm{Cu}$ of $\mathrm{T} 7$ was similar to that of T6 but significantly higher than those of T1, T2, T3, T4 and T5 (Table 4). Cation exchange capacity (CEC) and cations especially micronutrients of the soils with Leucaena leucocephala amendment (T7 and T6) were higher than those with only forest litter, chicken litter, and cow dung amendments (T3, T4, and T5) because of the higher nutrients content. Exchangeable Fe of T1 was similar to those of T2 and T6 but significantly higher than those of T3, T4, $\mathrm{T} 5$, and T7. In addition, exchangeable Fe of T7 was similar to those of T5 and T6 but significantly higher than those of T1, T2, T3, and T4 because tropical acid soils are inherently higher in Fe and moreover, there was no ammonia volatilization in T1. Furthermore, Fe hydrolysis was slower thereby maintaining the high Fe content of 
T1. The reduction in $\mathrm{Fe}$ of $\mathrm{T} 2$ was because of $\mathrm{Fe}$ hydrolysis following application of urea as this reaction might have catalysed the reaction of $\mathrm{H}^{+}$to produce ammonia. However, the higher $\mathrm{Fe}$ of $\mathrm{T} 6$ was because Leucaena leucocephala are $\mathrm{Fe}$ tolerant leguminous trees. Iron is reported to be high in the biomass of Leucaena leucocephala (Araújo \& Costa, 2013).

Table 4. Effects of soil organic amendments on soil chemical properties over forty-two days of ammonia volatilization

\begin{tabular}{|c|c|c|c|c|c|c|c|}
\hline Treatments & T1 & T2 & T3 & T4 & T5 & T6 & T7 \\
\hline $\mathrm{pH}$ in water & $5.67 \mathrm{~d} \pm 0.09$ & $6.63 c \pm 0.06$ & $6.67 \mathrm{bc} \pm 0.04$ & $6.67 \mathrm{bc} \pm 0.04$ & $6.89 \mathrm{abc} \pm 0.02$ & $6.96 \mathrm{ab} \pm 0.04$ & $7.05 \mathrm{a} \pm 0.11$ \\
\hline $\mathrm{pH}$ in $\mathrm{KCl}$ & $4.14 \mathrm{~d} \pm 0.01$ & $4.74 \mathrm{c} \pm 0.03$ & $4.75 c \pm 0.01$ & $5.03 \mathrm{~b} \pm 0.03$ & $5.13 \mathrm{ab} \pm 0.06$ & $5.17 \mathrm{ab} \pm 0.01$ & $5.30 \mathrm{a} \pm 0.07$ \\
\hline \multicolumn{8}{|c|}{ 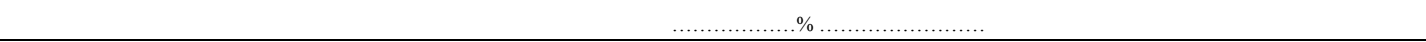 } \\
\hline Total carbon & $2.40 \mathrm{~b} \pm 0.04$ & $2.48 b \pm 0.04$ & $3.33 \mathrm{a} \pm 0.10$ & $3.21 \mathrm{a} \pm 0.10$ & $3.33 \mathrm{a} \pm 0.04$ & $3.60 \mathrm{a} \pm 0.58$ & $3.36 \mathrm{a} \pm 0.12$ \\
\hline Total N & $0.08 \mathrm{~b} \pm 0.01$ & $0.08 \mathrm{~b} \pm 0.01$ & $0.10 \mathrm{ab} \pm 0.02$ & $0.14 \mathrm{ab} \pm 0.02$ & $0.10 \mathrm{ab} \pm 0.01$ & $0.10 \mathrm{ab} \pm 0.01$ & $0.16 \mathrm{a} \pm 0.01$ \\
\hline \multicolumn{8}{|c|}{$\ldots \ldots \ldots \mathrm{mg} \mathrm{kg}^{-1} \ldots$} \\
\hline Available $\mathrm{NO}_{3}^{-}$ & $7.71 \mathrm{~d} \pm 0.40$ & $15.41 \mathrm{a} \pm 1.07$ & $8.41 \mathrm{dc} \pm 0.40$ & $12.61 \mathrm{ab} \pm 0.81$ & $13.78 \mathrm{a} \pm 0.47$ & $9.34 \mathrm{bcd} \pm 1.02$ & $11.91 \mathrm{abc} \pm 0.40$ \\
\hline Exchangeable $\mathrm{NH}_{4}{ }^{+}$ & $8.41 \mathrm{~d} \pm 0.70$ & $40.63 \mathrm{a} \pm 0.40$ & $21.25 \mathrm{bc} \pm 0.84$ & $19.15 b c \pm 0.47$ & $19.15 b c \pm 0.62$ & $21.48 \mathrm{~b} \pm 0.84$ & $18.21 \mathrm{c} \pm 0.40$ \\
\hline Total P & $13.75 \mathrm{c} \pm 6.88$ & $76.67 \mathrm{abc} \pm 5.07$ & $99.33 \mathrm{abc} \pm 3.86$ & $196.25 \mathrm{a} \pm 34.48$ & $132.42 \mathrm{abc} \pm 64.87$ & $62.9 \mathrm{bc} \pm 5.23$ & $167.75 \mathrm{ab} \pm 9.09$ \\
\hline Available P & $3.35 \mathrm{e} \pm 0.26$ & $31.71 \mathrm{~b} \pm 3.14$ & $19.47 \mathrm{~cd} \pm 2.00$ & $60.87 \mathrm{a} \pm 1.93$ & $27.81 \mathrm{bc} \pm 1.29$ & $14.05 \mathrm{~d} \pm 0.91$ & $27.09 b c \pm 2.72$ \\
\hline & \multicolumn{7}{|c|}{$\ldots \ldots \ldots \ldots \ldots . . \mathrm{Cmol} \mathrm{kg}^{-1} \ldots \ldots \ldots \ldots \ldots$} \\
\hline Total K & $1.62 \mathrm{~d} \pm 0.07$ & $3.14 c \pm 0.25$ & $3.23 c \pm 0.03$ & $4.35 \mathrm{a} \pm 0.11$ & $3.44 \mathrm{bc} \pm 0.11$ & $3.49 \mathrm{bc} \pm 0.11$ & $3.99 \mathrm{ab} \pm 0.16$ \\
\hline Available K & $0.10 \mathrm{~d} \pm 0.01$ & $0.75 c \pm 0.08$ & $1.04 \mathrm{~b} \pm 0.06$ & $1.52 \mathrm{a} \pm 0.01$ & $1.09 b \pm 0.01$ & $1.39 \mathrm{a} \pm 0.05$ & $1.45 \mathrm{a} \pm 0.01$ \\
\hline Exchangeable Acidity & $1.77 a \pm 0.05$ & $0.72 b \pm 0.03$ & $0.35 \mathrm{c} \pm 0.03$ & $0.23 c \pm 0.02$ & $0.28 \mathrm{c} \pm 0.02$ & $0.23 c \pm 0.03$ & $0.22 \mathrm{c} \pm 0.02$ \\
\hline Exchangeable $\mathrm{Al}^{3+}$ & $0.62 \mathrm{a} \pm 0.02$ & N/D & N/D & N/D & N/D & N/D & N/D \\
\hline Exchangeable $\mathrm{H}^{+}$ & $1.15 \mathrm{a} \pm 0.04$ & $0.72 b \pm 0.03$ & $0.35 c \pm 0.03$ & $0.23 c \pm 0.02$ & $0.28 c \pm 0.02$ & $0.23 c \pm 0.03$ & $0.22 \mathrm{c} \pm 0.02$ \\
\hline Exchangeable $\mathrm{Na}^{+}$ & $0.05 \mathrm{~d} \pm 0.01$ & $0.10 \mathrm{~d} \pm 0.01$ & $0.36 \mathrm{c} \pm 0.01$ & $0.71 \mathrm{a} \pm 0.04$ & $0.40 \mathrm{c} \pm 0.01$ & $0.40 \mathrm{c} \pm 0.03$ & $0.51 b \pm 0.01$ \\
\hline Exchangeable $\mathrm{Ca}^{2+}$ & $0.005 \mathrm{~d} \pm 0.001$ & $0.085 \mathrm{~d} \pm 0.005$ & $0.703 c \pm 0.026$ & $1.105 \mathrm{ab} \pm 0.132$ & $0.907 b c \pm 0.024$ & $1.443 a \pm 0.081$ & $1.147 \mathrm{ab} \pm 0.067$ \\
\hline Exchangeable $\mathrm{Mg}^{2+}$ & $0.27 \mathrm{~d} \pm 0.02$ & $0.38 \mathrm{~d} \pm 0.01$ & $1.16 \mathrm{c} \pm 0.01$ & $1.62 \mathrm{a} \pm 0.07$ & $1.30 \mathrm{bc} \pm 0.02$ & $1.42 \mathrm{ab} \pm 0.09$ & $1.51 \mathrm{ab} \pm 0.03$ \\
\hline Exchangeable $\mathrm{Zn}^{2+}$ & $0.010 b c \pm 0.001$ & $0.008 \mathrm{c} \pm 0.001$ & $0.018 \mathrm{bc} \pm 0.001$ & $0.034 a \pm 0.002$ & $0.023 \mathrm{ab} \pm 0.001$ & $0.021 \mathrm{abc} \pm 0.001$ & $0.024 a b \pm 0.001$ \\
\hline Exchangeable $\mathrm{Cu}^{2+}$ & $0.005 \mathrm{c} \pm 0.001$ & $0.011 b \pm 0.001$ & $0.004 c \pm 0.001$ & $0.014 b \pm 0.002$ & $0.013 b \pm 0.001$ & $0.015 \mathrm{ab} \pm 0.001$ & $0.019 a \pm 0.002$ \\
\hline Exchangeable $\mathrm{Mn}^{2+}$ & $0.010 \mathrm{c} \pm 0.001$ & $0.011 \mathrm{c} \pm 0.001$ & $0.028 \mathrm{a} \pm 0.001$ & $0.030 \mathrm{~b} \pm 0.001$ & $0.023 b \pm 0.001$ & $0.021 b \pm 0.001$ & $0.020 \mathrm{~b} \pm 0.001$ \\
\hline Exchangeable $\mathrm{Fe}^{2+}$ & $11.65 \mathrm{a} \pm 0.56$ & $9.72 \mathrm{abc} \pm 0.11$ & $9.20 \mathrm{bcd} \pm 0.37$ & $6.22 \mathrm{e} \pm 0.44$ & $7.47 \mathrm{de} \pm 0.38$ & $10.09 \mathrm{ab} \pm 0.49$ & $7.81 \mathrm{cde} \pm 0.70$ \\
\hline CEC & $4.57 \mathrm{c} \pm 0.55$ & $4.80 \mathrm{c} \pm 0.17$ & $5.30 \mathrm{c} \pm 0.36$ & $5.83 \mathrm{bc} \pm 0.13$ & $7.10 \mathrm{ab} \pm 0.36$ & $6.23 \mathrm{abc} \pm 0.24$ & $7.67 \mathrm{a} \pm 0.42$ \\
\hline
\end{tabular}

Note: Different letters within a row indicate significant difference between means of four replicates \pm standard error using Tukey's test at $P \leq$ 0.05

\section{Conclusion}

The organic amendments in T3, T4, T5, T6, and T7 improved soil chemical properties but T6 and T7 caused higher ammonia loss compared with those of T3, T4, and T5. Treatments 3 and 5 retarded daily ammonia loss compared with T4, T6, and T7. The findings of this present study also revealed that the total ammonia loss from urea over a period of forty-two days depends on the influence of the organic amendments on urea hydrolysis. For example, there were emissions of ammonia from $\mathrm{T} 6$ and $\mathrm{T} 7$ because the decomposition of Leucaena leucocephala favours urea hydrolysis compared with those of T3, T4, and T5. Therefore, Leucaena leucocephala composts should be carefully co-applied with urea to minimize ammonia loss if the aim of using amendment is to improve $\mathrm{N}$ use efficiency and crop productivity.

\section{Conflict of Interests}

The authors declare that there is no conflict of interests regarding the publication of this paper.

\section{Acknowledgment}

Authors would like to acknowledge Ministry of Higher Education for Fundamental Research Grant Scheme (FRGS - 5524983), Malaysia, Mitsubishi Corporation, Japan, and Universiti Putra Malaysia for funding this study.

\section{References}

Ahmed, O. H., Aminuddin, H., \& Husni, M. H. A. (2006). Ammonia volatilization and ammonium accumulation from urea mixed with zeolite and triple superphosphate. Acta Agric Scand Sect B, Soil Plant Sci., 58, 
182-186. https://doi.org/10.1080/09064710701478271

Araujo, A. S. F., \& Monteiro, R. T. R. (2005). Plant bioassays to asses toxicity of textile sludge compost. Scientia Agricola (Piracicaba, Braz.), 62(3), 286-290. http://dx.doi.org/10.1590/S0103-90162005000300013

Basosi, R., Spinelli, D., Fierro, A., \& Jez, S. (2014). Mineral nitrogen fertilizers: environmental impact of production and use. Fertil. Compon. Uses Agric. Environ. Impacts, Nova science publishers. Lopez-Valdez, $F$ and Fernandez.

Bremner, J. M. (1965). Total Nitrogen. In C. A. Black, D. D. Evan, L. E. Ensminger, J. L. White, F. E. Clark, \& R. D. Dinauer (Eds.), Method of soil analysis part 2 (pp. 1149-1178). American Society of Agronomy. Madison, Wisconcin.

Castells, E., Peñuelas, J., \& Walentine, D. W. (2004). Are phenolic compounds released from the Mediterranean shrub Cistus albidus responsible for changes in N cycling in siliceous and calcareous soils. New Phytol., 162, 187-195. https://doi.org/10.1111/j.1469-8137.2004.01021.x

Chefetz, B., Hatcher, P. G., Hadar, Y., \& Chen, Y. (1996). Chemical and biological characterization of organic matter during composting of municipal solid waste. Journal of Environmental Quality, 25(4), 776-785. https://doi.org/10.2134/jeq1996.00472425002500040018x

Cheng, C. H., Lehmann, J., \& Engelhard, M. (2008). Natural oxidation of black carbon in soils: changes in molecular form and surface charge along a climosequence. Geochimica et Cosmochimica Acta, 72, 1598-1610. https://doi.org/10.1016/j.gca.2008.01.010

Choi, W. J., \& Chang, S. X. (2005). Nitrogen dynamics in cocomposted drilling wastes: Effects of compost quality and $15 \mathrm{~N}$ fertilization. Soil Biol. Biochem., 37, 2297-2305. https://doi.org/10.1016/j.soilbio.2005.04.007

Choi, W. J., Jin, S. A., Lee, S. M., Ro, H. M., \& Yoo, S. H. (2001). Corn uptake and microbial immobilization of $15 \mathrm{~N}$-labeled urea-N in soil as affected by composted pig manure. Plant Soil, 235, 1-9. https://doi.org/10.1023/A:1011896912888

Choi, W. J., Chang, S. X., Kwak, J. H., Jung, J. W., Lim, S. S., Yoon, K. S., \& Choi, S. M. (2007). Nitrogen transformations and ammonia volatilization losses from $15 \mathrm{~N}$-urea as affected by the co-application of composted pig manure. Canadian journal of soil science, 87(5), 485-493. https://doi.org/10.4141/CJSS07002

Clemente, R., Escolar, A., \& Bernal, P. (2006). Heavy metals fractionation and organic matter mineralisation in contaminated calcareous soil amended with organic materials. Bioresour. Technol., 97, 1894-1901. https://doi.org/10.1016/j.biortech.2005.08.018

Cottenie, A. (1980). Soil testing and plant testing as a basis for fertilizer recommendation. FAO Soil Bull., 38, 70-73.

Fageria, N. K. (2016). The use of nutrients in crop plants. CRC press. https://doi.org/10.1201/9781420075113

Fan, M. X., \& Mackenzie, A. F. (1993). Urea and phosphate interactions in fertilizer microsites: ammonia volatilization and $\mathrm{pH}$ changes. Soil Science Society of America Journal, 57(3), 839-845. https://doi.org/10.2136/sssaj1993.03615995005700030034x

Han, K. H., Choi, W. J., Han, G. H., Yun, S. I., Yoo, S. H., \& Ro, H. M. (2004). Urea-nitrogen transformation and compost-nitrogen mineralization in three different soils as affected by the interaction between both nitrogen inputs. Biol. Fertil. Soils, 39, 193-199. https://doi.org/10.1007/s00374-003-0704-4

IRRI, (2006). Bringing hope, improving lives. In: Strategic Plan, 2007-2015, pp 61. Manila.

Keeney, D. R., \& Nelson, D. W. (1982). Nitrogen- Inorganic Forms. In A. L. Page, D. R. Keeney, D. E., Baker, R. H. Miller, R. Jr. Ellis, \& D. J. Rhoades (2nd Eds.), Methods of Soil Analysis, Part 2, Madison: Agronomy Monograph 9; ASA and SSSA, Madison, Wisconsin, USA.

Kong, W. D., Zhu, Y. G., Fu, B. J., Han, X. Z., Zhang, L., \& He, J. Z. (2008). Effect of long-term application of chemical fertilizers on microbial biomass and functional diversity of a black soil. Pedosphere, 18(6), 801-808. https://doi.org/10.1016/S1002-0160(08)60076-4

MADA (1970, June 30). Muda Agricultural Development Authority. Paddy, fertilization. Retrieved from http://www.mada.gov.my/semakan-tanaman-padi

Maru, A., Haruna, O. A., \& Charles, P. W. (2015). Coapplication of Chicken Litter Biochar and Urea Only to 
Improve Nutrients Use Efficiency and Yield of Oryza sativa L. Cultivation on a Tropical Acid Soil. The Scientific World Journal, 2015. http://dx.doi.org/10.1155/2015/943853

Murphy, J., \& Riley, J. P. (1962). A modified single solution method for the determination of phosphate in natural waters. Analytical Chemistry Acta, 27, 31-36. https://doi.org/10.1016/S0003-2670(00)88444-5

Palanivell, P., Ahmed, O. H., \& Ab Majid, N. M. (2016). Minimizing ammonia volatilization from urea, improving lowland rice (cv. MR219) seed germination, plant growth variables, nutrient uptake, and nutrient recovery using clinoptilolite zeolite. Archives of Agronomy and Soil Science, 62(5), 708-724. https://doi.org/10.1080/03650340.2015.1077229

Palanivell, P., Ahmed, O. H., \& Ab Majid, N. M. (2017). Minimizing Ammonia Volatilization from Urea in Waterlogged Condition Using Chicken Litter Biochar. Communications in Soil Science and Plant Analysis, 48, 1-10. https://doi.org/10.1080/00103624.2017.1406497

Paramanathan, S. (2000). Soils of Malaysia: Their characteristics and identification. Academic Science Malaysia, Kuala Lumpur, 1, 1-616.

Peech, H. M. (1965). Hydrogen-ion Activity. In C. A. Black, D. D. Evan, L. E. Ensminger, J. L. White, F. E. Clark, \& R. C. Dinaue (Eds.), Method of Soil Analysis, Part 2 (pp. 914-926). Ithaca: American society of Agronomy, Madison, Wisconsin.

Prasertsak, P., Freney, J. R., Saffigna, P. G., Denmead, O. T., \& Prove, B. G. (2001). Fate of urea nitrogen applied to a banana crop in the wet tropics of Queensland. Nutrient Cycling in Agroecosystems, 59(1), 65-73. https://doi.org/10.1023/A:1009806826141

Rowell, D. (1994). Soil Science; Methods and Applications, Department of Soil Science, University of Reading.

SAS, (2011). SAS/STAT Ssoftware. SAS Institute, (2nd ed.) Cary, NC. 16.

Siva, K. B., Aminuddin, H., Husni, M. H. A., \& Manas, A. R. (1999). Ammonia volatilization from urea as affected by tropical-based palm oil mill effluent (Pome) and peat. Commun Soil Sci Plant Anal., 30, 785-804. https://doi.org/10.1080/00103629909370246

Tan, K. H. (2005). Soil Sampling, Preparation and Analysis. (2nd ed.), pp. 154-174 (1-623). Taylor and Francis Group. Boca Raton, Florida, USA, CRC Press.

Zhou, J., Xia, F., Liu, X., He, Y., Xu, J., \& Brookes, P. C. (2014). Effects of nitrogen fertilizer on the acidification of two typical acid soils in South China. Journal of soils and sediments, 14(2), 415-422. https://doi.org/10.1007/s11368-013-0695-1

\section{Copyrights}

Copyright for this article is retained by the author(s), with first publication rights granted to the journal.

This is an open-access article distributed under the terms and conditions of the Creative Commons Attribution license (http://creativecommons.org/licenses/by/3.0/). 